\title{
1 Unusual amino acid derivatives from the mushroom Pleurocybella porrigens
}

2 Takumi Kawaguchi, Tomohiro Suzuki, Yuka Kobayashi, Shinya Kodani, Hirofumi Hirai, Kaoru Nagai, and Hirokazu Kawagishi*

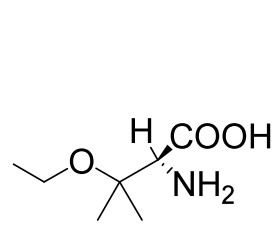

1

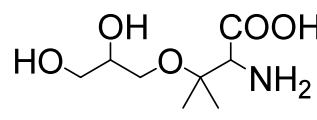

2

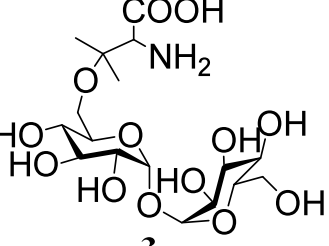

3

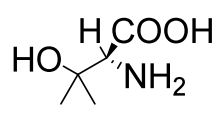

4

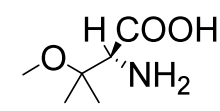

5

\author{
$\mathrm{COOH}$
}


1 Unusual amino acid derivatives from the mushroom Pleurocybella porrigens

2

3 Takumi Kawaguchi ${ }^{\mathrm{a}}$, Tomohiro Suzuki ${ }^{\mathrm{b}}$, Yuka Kobayashi ${ }^{\mathrm{a}}$, Shinya Kodani ${ }^{\mathrm{a}, \mathrm{b}}$, Hirofumi

4 Hirai $^{\mathrm{a}}$, Kaoru Nagai ${ }^{\mathrm{c}}$, and Hirokazu Kawagishi ${ }^{\mathrm{a}, \mathrm{b},{ }^{*}}$

5

$6{ }^{a}$ Department of Applied Biological Chemistry, Faculty of Agriculture, Shizuoka

7 University, 836 Ohya, Suruga-ku, Shizuoka 422-8529, Japan

$8{ }^{\mathrm{b}}$ Graduate School of Science and Technology, Shizuoka University, 836 Ohya, Suruga-

$9 \quad k u$, Shizuoka 422-8529, Japan

$10{ }^{\mathrm{c}}$ Department of Epigenetic Medicine, Interdisciplinary Graduate School of Medicine

11 and Engineering, University of Yamanashi, Yamanashi 409-3898, Japan

12

13 *Address all correspondence to Hirokazu Kawagishi, Graduate School of Science and

14 Technology, Shizuoka University, 836 Ohya, Suruga-ku, Shizuoka 422-8529, Japan;

15 Tel/Fax: +81-54-238-4885; achkawa@agr.shizuoka.ac.jp

16 
1 Abstract - Three new amino acid derivatives (1-3) and three known ones (4-6) were

2 isolated from the mushroom Pleurocybella porrigens. The structures of 1-6 were

3 determined by the interpretation of spectroscopic data. Compounds $\mathbf{1 , 3 , 4}$, and 5 were

4 toxic to mouse cerebrum glial cells.

5 


\section{Introduction}

2

3 The mushroom Pleurocybella porrigens (Angel's wings in English; Sugihiratake

4 in Japanese) is widespread and common throughout temperature regions of the world. It

5 has been eaten for a long time all over the world. However, in autumn 2004 in Japan,

6 fifty-five people got poisoned by eating this mushroom, and seventeen people among

7 them died of acute encephalopathy.

8 Epidemiological investigation found that the most patients had been on

9 hemodialysis treatment for chronic renal failure and had digested the fruiting bodies of

10 the fungus between one day and two weeks before the onset of neurological symptoms ${ }^{1-}$

$11^{3}$. Therefore, highly possible cause of the incident was identified to be the fruiting

12 bodies. The fruiting bodies cannot be cultivated artificially. Local people harvest and

13 consume the fruiting bodies that grow in the forest during the late summer and autumn.

14 However, there had been no report regarding toxicity of the fruiting bodies until the 15 incident.

16 After the incident, several chemical investigations have been accomplished on the

17 mushroom $P$. porrigens. Sasaki et al. performed the comparative chemical analyses on

18 the fruiting bodies that were collected at the various areas including the region of acute

19 encephalopathy incidents in Japan ${ }^{4}$. As a result, the high content of vitamin D analogues

20 was found in the fruiting bodies collected in the regions where acute encephalopathy

21 incidents happened. The involvement of aberrant calcium metabolism caused by the

22 vitamin D-related compounds was claimed to cause the acute encephalopathy in the

23 paper ${ }^{4}$. Ohta et al. isolated a cytotoxic ketonic fatty acid, 14-hydroxy-9-oxooctadeca-10,

24 12-dienoic acid, from the mushroom ${ }^{5}$. The ketonic acid exhibited toxicity to human

25 myeloma cells and murine melanoma cells. Ohta et al. also suggested that $N$ - 
1 glycolylneuraminic acid in the mushroom might be related to the incidents ${ }^{6}$. In addition,

2 we have reported the purification, characterization and cDNA cloning of a lectin from

3 the mushroom ${ }^{7}$. However, relationship between the chemical constituents and the acute

4 encephalopathy incidents has not been clarified yet.

5 Under these circumstances, we tried to isolate toxic compounds against a kind of 6 brain cells, glial cells, from the mushroom. As a result, six compounds (1-6) including

7 three novel ones (1-3) were isolated from the mushroom. Here we report the isolation, 8 structural determination, and toxicity of the compounds.

9 


\section{2. Results and Discussion}

$2 \quad$ Lyophilized fruiting bodies of Pleurocybella porrigens were successively

3 extracted with hexane, EtOAc, EtOH, $\mathrm{H}_{2} \mathrm{O}$, and then boiled $\mathrm{H}_{2} \mathrm{O}$. The EtOH fraction

4 which showed cytotoxicity to mouse glial cells was subjected to open silica gel column

5 chromatography, eluting with stepwise by acetone and $90 \% \mathrm{MeOH}$. The $90 \% \mathrm{MeOH}$

6 fraction was separated with repeated HPLC to afford compounds 1-6.

Compound 1 was isolated as white crystals, and its HR-ESIMS analysis data

8 indicated the molecular formula of $\mathrm{C}_{7} \mathrm{H}_{16} \mathrm{NO}_{3}$. The analyses of ${ }^{1} \mathrm{H}-\mathrm{NMR},{ }^{13} \mathrm{C}-\mathrm{NMR}$,

9 DEPT and HMQC spectra indicated the presence of three methyls, a methylene, a

10 methine, a quaternary carbon, and a carboxyl (Table 1). The moiety of 2-amino-3-

11 methylbutanoic acid (2-hydroxyvaline) was constructed by the HMBC correlations

$12\left(\mathrm{H} 2 / \mathrm{C} 1, \mathrm{H} 2 / \mathrm{C} 3, \mathrm{H} 2 / \mathrm{C} 4, \mathrm{H} 2 / 3-\mathrm{CH}_{3}, \mathrm{H} 4 / \mathrm{C} 2, \mathrm{H} 4 / \mathrm{C} 3, \mathrm{H} 4 / 3-\mathrm{CH}_{3}, 3-\mathrm{CH}_{3} / \mathrm{C} 2,3-\mathrm{CH}_{3} / \mathrm{C} 3\right.$,

13 and $3-\mathrm{CH}_{3} / \mathrm{C} 4$ ) as shown in Fig. 1. The presence of an ethoxy group was suggested by

14 COSY correlation between $\mathrm{H} 1^{\prime}$ and $\mathrm{H} 2$ ' and $\mathrm{HMBC}$ correlation from $\mathrm{H} 2$ ' to $\mathrm{C} 1^{\prime}$ and

$15 \mathrm{H} 1$ ' to $\mathrm{C} 2$ '. The linkage between the 2-hydroxyvaline moiety and the ethoxy group was

16 determined by HMBC correlation from $\mathrm{H} 1$ ' to $\mathrm{C} 3$. Therefore, the planar structure of $\mathbf{1}$

17 was determined as 2-amino-3-ethoxy-3-methylbutanoic acid.

18 Compound 2 was isolated as white crystals and the HR-ESIMS analysis data

19 indicated the molecular formula of $\mathrm{C}_{8} \mathrm{H}_{17} \mathrm{NO}_{5}$. The analyses of ${ }^{1} \mathrm{H}-\mathrm{NMR},{ }^{13} \mathrm{C}-\mathrm{NMR}$,

20 DEPT and HMQC spectra indicated the presence of two methyls, two methylenes, two

21 methines, a quaternary carbon, and a carboxyl (Table 1.). The HMBC data indicated

22 that this compound also had a 2-hydroxyvaline moiety (Fig. 1). The HMBC correlations

$23\left(\mathrm{H}^{\prime}\right.$ '/C2', H1'/C3', H2'/C1', H2'/C3', H3'/C2', H3'/C1'), downfield-shifted chemical

24 shift values $\left(\mathrm{H} 2{ }^{\prime} \delta 3.69 ; \mathrm{C} 2{ }^{\prime} \delta 71.7 ; \mathrm{H}^{\prime}{ }^{\prime} \delta 3.43,3.46 ;{ }^{\prime} 3^{\prime} \delta 63.3\right)$, and the molecular

25 formula indicated the presence of a 2,3-dihydroxypropoxy residue. The linkage of this 
1 residue to $\mathrm{C} 3$ through an oxygen atom was suggested by the HMBC correlation

2 (H1'/C3). All the data suggested that 2 was 2-amino-3-(2,3-dihydroxypropoxy)- 3,3-

3 dimethylpropanoic acid.

4 Compound 3 was isolated as white crystals, and the HR-ESIMS data analysis

5 indicated the molecular formula of $\mathrm{C}_{17} \mathrm{H}_{31} \mathrm{NO}_{13}$. The analyses of ${ }^{1} \mathrm{H}-\mathrm{NMR},{ }^{13} \mathrm{C}-\mathrm{NMR}$,

6 DEPT, HMQC and HMBC spectra indicated the presence of two methyls, two

7 methylenes, eleven methines, a quaternary carbon, and a carboxyl (Table 1) and also

8 suggested the involvement of a 3-hydroxyvaline residue as $\mathbf{1}$ and $\mathbf{2}$. Judging from the

9 results that the rest of the structure had the formula of $\mathrm{C}_{12} \mathrm{H}_{23} \mathrm{O}_{12}$ and the characteristic

10 signals of two anomeric protons $(H 1$ ' $\delta 5.04 ; \mathrm{C} 1$ ' $\delta$ 94.4; $\mathrm{H} 1$ ” $\delta 5.02 ; \mathrm{C} 1$ ” $\delta$ 94.3) were

11 observed in the NMR spectra, the presence of a disaccharide was indicated. Sugar

12 composition analysis of the compound detected Glc only. The ${ }^{1} \mathrm{H}-$ and ${ }^{13} \mathrm{C}-\mathrm{NMR}$ data of

13 the saccharide part in $\mathbf{3}$ were very similar to those of trehalose (Table 1). The coupling

14 constants of two anomeric protons $(J=3.7 \mathrm{~Hz}$ and $3.9 \mathrm{~Hz})$ and the HMBC correlations

15 (H1'/C1", H1"/C1') confirmed that the disaccharide was $\alpha, \alpha$-trehalose. Since the

16 specific rotation of $3\left([\alpha]^{30}{ }_{D}+130\left(\mathrm{H}_{2} \mathrm{O}, c 0.10\right)\right)$ was similar to that of $\alpha, \alpha$-trehalose

17 ( $\alpha$-D-glucopyranosyl- $\alpha$-D-glucopyranoside) $\left([\alpha]^{30}{ }_{D}+178\left(\mathrm{H}_{2} \mathrm{O}, c 7.0\right)\right.$, the constituent

18 sugar in 3 was deduced to be D-Glc. The ether bond between C6' and C3 was indicated

19 by the HMBC correlation from $\mathrm{H}^{\prime}$ to $\mathrm{C} 3$ and the downfield-shifted chemical shifts

$20 \quad\left(\mathrm{H} 6^{\prime} \delta 3.57,3.73 ; \mathrm{C}^{\prime} \delta \mathrm{\delta} 60.9 ; \mathrm{C} \delta \mathrm{\delta} 75.8\right)$. Therefore, the structure of $\mathbf{3}$ was deduced to

21 be as shown.

22 Compounds 4,5 , and 6 were identified as 2-amino-3-hydroxy-3-methylbutanoic

23 acid, 2-amino-3-methoxy-3-methylbutanoic acid, and 3-amino-2-hydroxy-3-

24 methylbutanoic acid, respectively, by the analyses of spectroscopic data. Compound 4

25 has been synthesized and isolated from this mushroom ${ }^{8,9}$. Compounds 5 and $\mathbf{6}$ have 
1 been already synthesized ${ }^{10,11}$. However, this report is the first isolation of 5 and $\mathbf{6}$ from

2 a natural source.

3 The absolute configurations of $\mathbf{4}$ and $\mathbf{5}$ were determined to be $S$ by comparison of

4 their specific rotation values with those reported previously ${ }^{11,12}: 4,[\alpha]^{30}{ }_{D}+3.8\left(\mathrm{H}_{2} \mathrm{O}, c\right.$

5 0.13), reported data, $[\alpha]^{30}{ }_{D}+4.0\left(\mathrm{H}_{2} \mathrm{O}, c 0.20\right) ; 5,[\alpha]^{30}+10\left(\mathrm{H}_{2} \mathrm{O}, c 0.4\right)$, reported data,

$6[\alpha]^{30}{ }_{D}+11.0\left(\mathrm{H}_{2} \mathrm{O}, c\right.$ 3.0). The absolute configuration of 1 was deduced as $S$, because its

7 structure and specific rotation $\left([\alpha]^{30}{ }_{\mathrm{D}}+9.4, \mathrm{H}_{2} \mathrm{O}, c 0.20\right)$ were very similar to those of $\mathbf{5}$,

8 respectively. The stereochemistry of $\mathbf{2 , 3}$, and $\mathbf{6}$ remains unknown.

$9 \quad$ Cytotoxicity of $\mathbf{1}$ and $\mathbf{3}$ - $\mathbf{6}$ against mouse cerebrum glial cells was evaluated.

10 Compounds $\mathbf{1}, \mathbf{3}, \mathbf{4}$, and $\mathbf{5}$ showed weak toxicity to the cells at $10 \mu \mathrm{g} / \mathrm{mL}$ but $\mathbf{6}$ exhibited

11 no activity (Table 2). This result indicates that the 2-hydroxyvaline moiety is

12 indispensable to the cytotoxicity. However, the relationship between the cytotoxicity of

13 the compounds and the acute encephalopathy in human remains unsolved.

14 


\section{3. Experimental}

2

\section{3.1. General}

$4 \quad{ }^{1} \mathrm{H}$ NMR spectra (one- and two-dimensional) were recorded on a JEOL lambda-500

5 spectrometer at $500 \mathrm{MHz}$, while ${ }^{13} \mathrm{C}$ NMR spectra were recorded on the same

6 instrument at $125 \mathrm{MHz}$. The HRESIMS spectra were measured on a JMS-T100LC mass

7 spectrometer. A JASCO grating infrared spectrophotometer was used to record the IR

8 spectra. HPLC separations were performed with a JASCO Gulliver system using a

9 preparative column (Develosil C30-UG-5, Nomura chemical, Japan; Cosmosil HILIC

10 Waters, Nakalai Tesque, Japan). Silica gel plate $\left(\right.$ Merck $\left.F_{254}\right)$ and silica gel $60 \mathrm{~N}($ Merck

11 100-200 mesh) were used for analytical TLC and for flash column chromatography,

12 respectively. Wakosil-II 5C18HG for sugar composition analysis was a product of

13 Wako Pure Chemicals, Japan.

14

\section{$15 \quad$ 3.2. Fungus materials}

16 Fruiting bodies of $P$. porrigens were collected in Yamanashi Prefecture, Japan, in

17 October 2004.

18

\subsection{Extraction and isolation}

20 The fresh fruiting bodies of $P$. porrigens $(4.0 \mathrm{~kg})$ were lyophilized, and

21 successively extracted with hexane, EtOAc, EtOH, $\mathrm{H}_{2} \mathrm{O}$, and boiled $\mathrm{H}_{2} \mathrm{O}$ (3 L, four

22 times, respectively). Each solution was concentrated under reduced pressure and the

23 EtOH-soluble part (10.1 g) was fractionated by silica gel flash column chromatography,

24 eluting with stepwise by acetone and 90\% $\mathrm{MeOH}$. The $90 \% \mathrm{MeOH}$ fraction $(6.0 \mathrm{~g})$ was

25 separated by reversed-phase HPLC to obtain 25 fractions (column, Develosil C30-UG-5 
$150 \times 500 \mathrm{~mm}$; solvent, 20\% MeOH; flow rate, $25 \mathrm{ml} / \mathrm{min}$; UV absorbance, $220 \mathrm{~nm}$ ). The

2 tenth fraction (Rt $75.0 \mathrm{~min}$ ) was separated by HPLC (column, Cosmosil HILIC Waters

$320 \times 250 \mathrm{~mm}$; solvent, acetonitrile/ $\mathrm{H}_{2} \mathrm{O}(85: 15)$; flow rate, $5 \mathrm{ml} / \mathrm{min}$; UV absorbance,

$4220 \mathrm{~nm}$ ), to afford 5 (1.5 $\mathrm{mg}$; Rt $14.5 \mathrm{~min})$. The twenty-fourth fraction (Rt $192.5 \mathrm{~min}$ )

5 was also separated by HPLC in the same manner, with acetonitrile/ $\mathrm{H}_{2} \mathrm{O}(90: 10)$ to yield

$61(2.3 \mathrm{mg} ;$ Rt $12.1 \mathrm{~min})$. Furthermore, the sixteenth fraction (Rt $122.2 \mathrm{~min})$ was

7 separated by HPLC in the same manner, with acetonitrile/ $\mathrm{H}_{2} \mathrm{O}(85: 15)$ to yield $2(0.8$

$8 \mathrm{mg} ;$ Rt $18.1 \mathrm{~min}$ ). The fourth fraction (Rt $59.4 \mathrm{~min}$ ) was separated by HPLC with

9 acetonitrile $/ \mathrm{H}_{2} \mathrm{O}(80: 20)$ to yield 3 (1.3 mg; Rt $\left.25.8 \mathrm{~min}\right), 4$ (4.0 mg; Rt $\left.14.5 \mathrm{~min}\right)$, and 6

$10 \quad$ (0.7 mg; Rt $15.7 \mathrm{~min})$.

11

12 3.3.1. Compound 1; $[\alpha]^{30}{ }_{D}+9.4\left(\mathrm{H}_{2} \mathrm{O}, c\right.$ 0.20); HRESIMS $m / z 184.0950[\mathrm{M}+\mathrm{Na}]^{+}$

13 (calcd for $\mathrm{C}_{7} \mathrm{H}_{15} \mathrm{NaNO}_{3}, 184.0980$ ); $\mathrm{mp} 180-182^{\circ} \mathrm{C}$; IR $v_{\max }(\mathrm{KBr}) \mathrm{cm}^{-1}: 1734$

15 3.3.2. Compound 2; $[\alpha]^{30}{ }_{\mathrm{D}}+12\left(\mathrm{H}_{2} \mathrm{O}, c\right.$ 0.08); HRESIMS $m / z 230.1004[\mathrm{M}+\mathrm{Na}]^{+}$

16 (calcd for $\mathrm{C}_{8} \mathrm{H}_{17} \mathrm{NaNO}_{5}, 230.1017$ ); $\mathrm{mp} 175-177^{\circ} \mathrm{C}$; IR $v_{\max }(\mathrm{KBr}) \mathrm{cm}^{-1}: 3628,1732$.

17

18 3.3.3. Compound 3; $[\alpha]^{30}{ }_{\mathrm{D}}+130\left(\mathrm{H}_{2} \mathrm{O}, c\right.$ 0.10); HRESIMS $m / z 480.1693[\mathrm{M}+\mathrm{Na}]^{+}$

19 (calcd for $\mathrm{C}_{17} \mathrm{H}_{31} \mathrm{NaNO}_{13}, 480.1703$ ); mp 140-142 ${ }^{\circ} \mathrm{C}$; IR $v_{\max }(\mathrm{KBr}) \mathrm{cm}^{-1}: 3426,1734$.

20

21 3.3.4. Compound 4; $[\alpha]^{30}{ }_{\mathrm{D}}+3.8\left(\mathrm{H}_{2} \mathrm{O}, c 0.13\right)$; ESIMS $m / z 156.0637[\mathrm{M}+\mathrm{Na}]^{+} ;{ }^{1} \mathrm{H}-$

22 NMR (in $\left.\mathrm{D}_{2} \mathrm{O}\right): 1.08\left(3 \mathrm{H}, \mathrm{s}, 3-\mathrm{CH}_{3}\right), 1.30\left(3 \mathrm{H}, \mathrm{s}, 3-\mathrm{CH}_{3}\right), 3.44(1 \mathrm{H}, \mathrm{s}, \mathrm{H}-2) ;{ }^{13} \mathrm{C}-\mathrm{NMR}$ (in $\left.23 \mathrm{D}_{2} \mathrm{O}\right): 24.0\left(3-\mathrm{CH}_{3}\right), 28.1\left(3-\mathrm{CH}_{3}\right), 64.2(\mathrm{C}-2), 70.6(\mathrm{C}-3), 172.9(\mathrm{C}-1)$

24 
1 3.3.5. Compound 5; $[\alpha]^{30}{ }_{\mathrm{D}}+10\left(\mathrm{H}_{2} \mathrm{O}, c\right.$ 0.4) ESIMS $m / z 170.0793[\mathrm{M}+\mathrm{Na}]^{+} ;{ }^{1} \mathrm{H}-\mathrm{NMR}$

2 (in $\left.\mathrm{D}_{2} \mathrm{O}\right): 1.05\left(3 \mathrm{H}, \mathrm{s}, 3-\mathrm{CH}_{3}\right), 1.27\left(3 \mathrm{H}, \mathrm{s}, 3-\mathrm{CH}_{3}\right), 3.09(3 \mathrm{H}, \mathrm{s}, \mathrm{H}-1$ '), $3.60(1 \mathrm{H}, \mathrm{s}, \mathrm{H}-2)$;

$3{ }^{13} \mathrm{C}-\mathrm{NMR}$ (in $\left.\mathrm{D}_{2} \mathrm{O}\right): 20.9\left(3-\mathrm{CH}_{3}\right), 22.9\left(3-\mathrm{CH}_{3}\right), 49.9\left(\mathrm{C}-1^{\prime}\right), 61.6(\mathrm{C}-2), 75.6(\mathrm{C}-3)$,

$4 \quad 172.7(\mathrm{C}-1)$

5

6 3.3.6. Compound 6; $[\alpha]^{30}{ }_{\mathrm{D}}+12\left(\mathrm{H}_{2} \mathrm{O}, c\right.$ 0.07); ESIMS $m / z 156.0620[\mathrm{M}+\mathrm{Na}]^{+} ;{ }^{1} \mathrm{H}-$

$7 \quad \mathrm{NMR}\left(\right.$ in $\left.\mathrm{D}_{2} \mathrm{O}\right): 1.18\left(3 \mathrm{H}, \mathrm{s}, 3-\mathrm{CH}_{3}\right), 1.23\left(3 \mathrm{H}, \mathrm{s}, 3-\mathrm{CH}_{3}\right), 3.78(1 \mathrm{H}, \mathrm{s}, \mathrm{H}-2) ;{ }^{13} \mathrm{C}-\mathrm{NMR}$ (in $\left.8 \quad \mathrm{D}_{2} \mathrm{O}\right): 22.1\left(3-\mathrm{CH}_{3}\right), 22.2\left(3-\mathrm{CH}_{3}\right), 56.7(\mathrm{C}-3), 76.1(\mathrm{C}-2), 177.5(\mathrm{C}-1)$

\subsection{Sugar composition analysis}

11 Sugar composition was determined as described previously ${ }^{12}$. Briefly, the sample $12(200 \mu \mathrm{g})$ was dissolved in $20 \mu \mathrm{l}$ distilled water in a test tube to which $6 \mathrm{M}$ TFA $(20 \mu \mathrm{l})$

13 was added. The test tube was incubated at $100^{\circ} \mathrm{C}$ in a hot block bath. After $6 \mathrm{~h}$, the tube

14 was cooled to room temperature and the acid was removed by using a centrifugal

15 concentrator at $35{ }^{\circ} \mathrm{C}$. The dried sample was derivatized with $p$-aminobenzoic ethyl

16 ether in the presence of borane-pyridine complex at $80^{\circ} \mathrm{C}$. After $1 \mathrm{~h}$, the reaction

17 mixture was cooled to room temperature. Distilled water (200 $\mu 1)$ and an equal volume

18 of chloroform were added to the reaction mixture. After vigorous vortexing, the sample 19 was centrifuged $(6000 \times \mathrm{g}, 1 \mathrm{~min})$. The upper aqueous layer was analyzed by reversed20 phase HPLC under the following conditions: column, Wakosil-II 5C18HG $(4.6 \times 250$

$21 \mathrm{~mm})$; solvent, A $0.02 \% \mathrm{TFA} / \mathrm{CH}_{3} \mathrm{CN}(90 / 10)$, B 0.02\% TFA/ $\mathrm{CH}_{3} \mathrm{CN}$ (50/50); program,

$22 \quad 0-70 \min (\mathrm{B}$ conc. 0\%), 70-80 $\min$ (B conc. 100\%), 80-90 $\min$ (B conc. 0\%); flow rate,

$231.5 \mathrm{ml} / \mathrm{min}$; temp., $45^{\circ} \mathrm{C}$; detection, absorbance at $360 \mathrm{~nm}$. The monosaccharide and

24 amino monosaccharide standards used were D-GlcNAc, D-GalNAc, D-Glc, D-Gal, D25 Man, D-Xyl, and L-Fuc.. 


\section{$2 \quad 3.5$. Bioassay}

3 Primary cultured mouse glial cells were prepared from the cortex of embryonic day

418 C57BL/6 mice. All animal experiments were approved by the University of

5 Yamanashi Animal Care and Use Committee. The cells were cultured in Dulbecco's

6 modified Eagles medium (D-MEM) supplemented with 10\% heat-inactivated fetal

7 bovine serum, penicillin $(100 \mathrm{U} / \mathrm{ml})$, and streptomycin $(100 \mu \mathrm{g} / \mathrm{ml})$ at $37^{\circ} \mathrm{C}$ in a

8 humidified 5\% $\mathrm{CO}_{2}$ atmosphere. After 1 week of culture in this medium, the cells were

9 passaged and used as a glial cell culture.

10 Samples at various concentrations were added to the glial cells cultured in D-MEM

11 without serum. The cells were cultured for 48 hours. After incubation, the cell

12 viabilities were analyzed by 3-(4,5-dimethyl-2-thiazolyl)-2,5-diphenyl-2H-tetrazolium

13 bromide (MTT, Dojindo, Kumamoto) colorimetric assay. Briefly, treated glial cells

14 were incubated with MTT $(250 \mu \mathrm{g} / \mathrm{ml})$ in D-MEM without serum for $2 \mathrm{~h}$. The reaction

15 was terminated by adding $20 \%(\mathrm{w} / \mathrm{v})$ sodium dodecylsulfate and $50 \%(\mathrm{v} / \mathrm{v})$

16 dimethylformamide in water. The number of living cells was quantified by measuring

17 absorbance at $570 \mathrm{~nm}$.

\section{Acknowledgement}

20 This work was partially supported by grant-in-aid for scientific research on

21 priority areas 'Creation of Biologically Functional Molecules' (No. 17035037) from the

22 Ministry of Education, Culture, Sports, Science and Technology of Japan, and grant-in-

23 aid for research and development projects for application in promoting new policy of

24 agriculture forestry and fisheries from the Ministry of Agriculture, Forestry and

25 Fisheries. 


\section{$1 \quad$ References}

2 1. Kuwabara, T.; Arai, A.; Honma, N.; Nishizawa, M. Rinsho Shinkeigaku 2005, 45, 3 239-245. (In Japanese with English abstract)

4 2. Obara, K.; Okawa, S.; Kobayashi, M.; Takahashi, S.; Watanabe, S.; Toyoshima, I.

$5 \quad$ Rinsho Shinkeigaku 2005; 45, 253-256. (In Japanese with English abstract)

6 3. Obara, K.; Wada, C.; Yoshioka, T.; Enomoto, K., Yagishita, S.; Toyoshima, I.

$7 \quad$ Neuropathology. 2008, 28, 151-156.

8 4. Sasaki, H.; Akiyama, H.; Yoshida, Y.; Kondo, K.; Amakura, Y.; Kasahara, Y.;

9 Maitani, T. Biol. Pharm. Bull. 2006, 29, 2514-2528.

10 5. Hasegawa, T.; Ishibashi, M.; Takata, T.; Takano, F.; Ohta, T. Chem. Pharm. Bull. 11 (Tokyo). 2007; 55, 1748-1749.

12 6. Takata, T.; Hasegawa, T.; Tatsuno, T.; Date, J.; Ishigaki, Y.; Nakamura, Y.;

13 Tomosugi, N.; Takano, F.; Ohta, T. J. Health Science 2009, 55, 373-379.

14 7. Suzuki, T.; Amano, Y.; Fujita, M.; Kobayashi, Y.; Dohra, H.; Hirai, H.; Murata, T.;

15 Usui, T.; Kawagishi, H. Biosci. Biotechnol. Biochem. 2009, 73, 702-709

16 8. Schrauth, W.; Geller, H. Chem. Ber. 1934, 67B, 530-547.

17 9. Aoyagi, Y.; Sugahara, T.; Phytochemistry, 1988, 27, 3306-3307.

18 10. Schrauth, W.; Geller, H. Chem. Ber. 1922, 55B, 2783-2796.

19 11. Fringuelli, F.; Pizzo, F.; Rucci, M.; Vaccaro, L. J. Org. Chem. 2003, 68, 7041-7045.

20 12. Yasuno, S.; Murata, T.; Kokubo, K.; Kamei, M. Biosci. Biotech. Biochem. 1997, 61, $21 \quad 1944-1946$.

22 
$1 \quad$ Figure legend

2

3 Fig. 1. COSY and HMBC correlations of $\mathbf{1}$ and $\mathbf{2}$ 


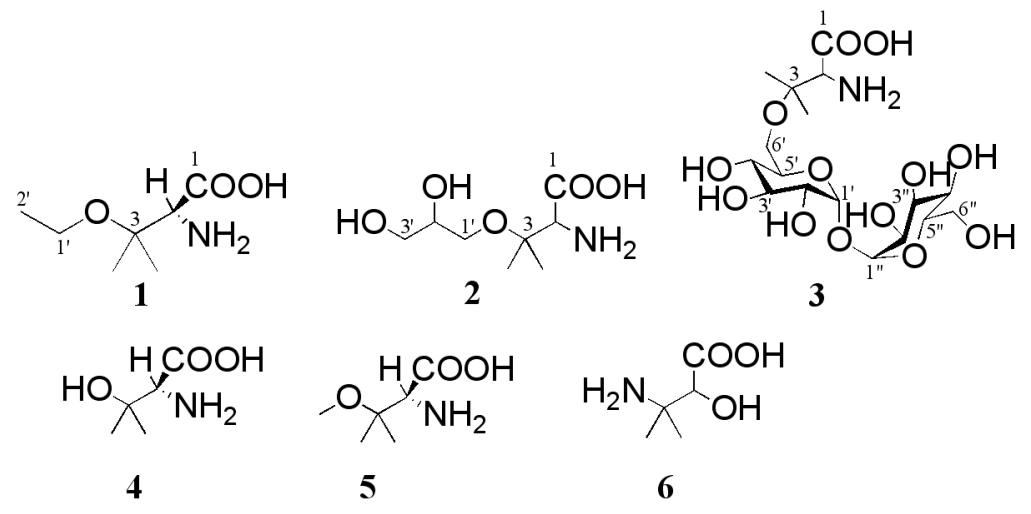

Kawaguchi et al. 

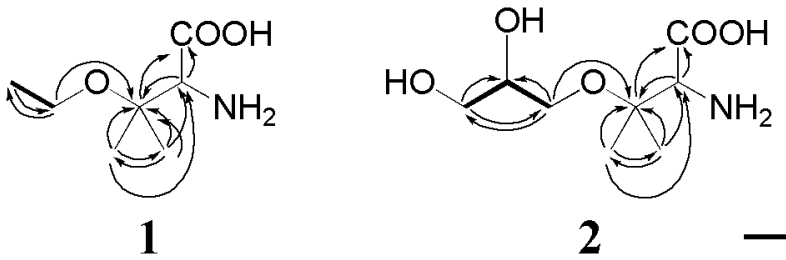

$2-\cos Y$

$\longrightarrow \mathrm{HMBC}$

Figure 1. Kawaguchi et al. 
Table 1. NMR data for 1-3 and treharose

\begin{tabular}{|c|c|c|c|c|c|}
\hline \multicolumn{3}{|l|}{$1 *$} & \multicolumn{3}{|l|}{2} \\
\hline Position & ${ }^{1} \mathrm{H}$ (multiplicity, $J \mathrm{~Hz}$ ) & ${ }^{13} \mathrm{C}$ & Position & ${ }^{1} \mathrm{H}$ (multiplicity, $J \mathrm{~Hz}$ ) & ${ }^{13} \mathrm{C}$ \\
\hline 1 & - & 172.7 & 1 & - & 172.7 \\
\hline 2 & $3.65(\mathrm{~s})$ & 62.0 & 2 & $3.61(\mathrm{~s})$ & 62.4 \\
\hline 3 & - & 75.5 & 3 & - & 75.6 \\
\hline \multirow[t]{2}{*}{$3-\mathrm{CH}_{3}$} & $1.34(\mathrm{~s})$ & 23.7 & $3-\mathrm{CH}_{3}$ & $1.34(\mathrm{~s})$ & 23.6 \\
\hline & $1.11(\mathrm{~s})$ & 21.3 & & $1.11(\mathrm{~s})$ & 21.0 \\
\hline 1 ' & $3.42(\mathrm{~m})$ & 58.4 & 1 ' & $\begin{array}{l}3.30(\mathrm{dd}, 10.1,7.0), 3.42 \\
(\mathrm{dd}, 10.1,3.5)\end{array}$ & 63.7 \\
\hline \multirow[t]{2}{*}{2 ' } & $1.05(\mathrm{t}, 7.0)$ & 15.7 & 2 ' & $3.69(\mathrm{~m})$ & 71.7 \\
\hline & & & 3 & $\begin{array}{l}3.40(\mathrm{dd}, 11.1,2.3) \\
3.48(\mathrm{dd}, 11.1,4.7)\end{array}$ & 63.3 \\
\hline 3 & & & trehalose & & \\
\hline Position & ${ }^{1} \mathrm{H}$ (multiplicity, $J \mathrm{~Hz}$ ) & ${ }^{13} \mathrm{C}$ & Position & ${ }^{1} \mathrm{H}$ (multiplicity, $J \mathrm{~Hz}$ ) & ${ }^{13} \mathrm{C}$ \\
\hline 1 & - & 172.6 & 1 & $4.88(\mathrm{~d}, 3.7)$ & 94.3 \\
\hline 2 & $3.64(\mathrm{~s})$ & 62.1 & 2 & $3.24(\mathrm{dd}, 4.3,3.7)$ & 72.14 \\
\hline 3 & - & 75.8 & 3 & $3.55(\mathrm{dd}, 9.0,4.3)$ & 73.65 \\
\hline \multirow[t]{2}{*}{$3-\mathrm{CH}_{3}$} & $1.31(\mathrm{~s})$ & 23.6 & 4 & $3.14(\mathrm{dd}, 9.8,9.0)$ & 70.81 \\
\hline & $1.12(\mathrm{~s})$ & 21.4 & 5 & $3.65(\mathrm{ddd}, 9.8,4.6,2.1)$ & 73.19 \\
\hline 1 ' & $5.04(\mathrm{~d}, 3.7)$ & 94.4 & 6 & $\begin{array}{l}3.47(\mathrm{dd}, 11.5,4.6,), 3.56 \\
(\mathrm{dd}, 11.5,2.1)\end{array}$ & 61.7 \\
\hline $1 "$ & $5.02(\mathrm{~d}, 3.9)$ & 94.3 & & & \\
\hline 2 ' & $3.52(\mathrm{~m})^{* *}$ & $71.8 * *$ & & & \\
\hline $2 "$ & $3.53(\mathrm{~m})^{* *}$ & $71.9 * *$ & & & \\
\hline $3{ }^{\prime}$ & $3.68(\mathrm{~m}) * *$ & $73.4^{* *}$ & & & \\
\hline $3 "$ & $3.70(\mathrm{~m}) * *$ & $73.5^{* *}$ & & & \\
\hline 4 ' & $3.30(\mathrm{dd}, 9.7,8.9)$ & 70.1 & & & \\
\hline $4 "$ & $3.41(\mathrm{dd}, 9.7,8.9)$ & 70.5 & & & \\
\hline 5 & $3.71(\mathrm{~m}) * *$ & $72.9 * *$ & & & \\
\hline $5 "$ & $3.75(\mathrm{~m}) * *$ & $72.9 * *$ & & & \\
\hline 6 & $3.57(\mathrm{~m}), 3.73(\mathrm{~m})$ & 60.9 & & & \\
\hline $6 "$ & $3.72(\mathrm{~m})$ & 61.1 & & & \\
\hline
\end{tabular}

* Concentration, 1 (6.4 mg/0.5 ml), 2 (2.2 mg/0.5 ml), 3 (3.6 mg/0.5 ml), treharose (12.0 mg/0.5 ml) ** interchangeable between positions, n' and n" 
Table 2. Toxicity to glial cells at $10 \mu \mathrm{g} / \mathrm{ml}$

\begin{tabular}{ll}
\hline Compound & Relative viability $^{*}$ \\
\hline $\mathbf{1}$ & $76 \pm 2^{* *}$ \\
$\mathbf{2}$ & $\mathrm{ND}^{* * *}$ \\
$\mathbf{3}$ & $84 \pm 3^{* *}$ \\
$\mathbf{4}$ & $79 \pm 1^{* *}$ \\
$\mathbf{5}$ & $80 \pm 1^{* *}$ \\
$\mathbf{6}$ & $101 \pm 1^{* *}$ \\
\hline
\end{tabular}

* The number indicates relative viability (\%) of glial cells to that of control. Data are the mean $\pm \mathrm{SE}$.

${ }^{* *} \mathrm{p}<0.01$ vs control using Student's $t$-test..

${ }^{* * *} \mathrm{ND}$; not determined 